\title{
Consumer Rental Car Choice: Price, Agent, and Brand Effects
}

Thomas L. Ainscough, University of South Florida St. Petersburg, USA

Philip J. Trocchia, University of South Florida St. Petersburg, USA

John R. Gum, University of South Florida St. Petersburg, USA

\begin{abstract}
Car rentals constitute a significant portion of vacation travel expenditures. This research study uses a model developed in prior literature to explore the effects of vehicle brand, rental agency image, and rental price on consumers' willingness to rent automobiles. Results indicate that branding and price impact consumers' decisions to rent motor vehicles. However, the influence of the agency on the rental decision is limited. Managerial implications of these findings are discussed.
\end{abstract}

Keywords: automobile rental, car rental, price, brand, agent

\section{INTRODUCTION}

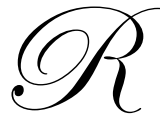

entals constitute a substantial portion of services provided to travelers and tourists. Such services include hotels and motel accommodations, vacation homes, and car rentals. Car rentals companies alone generated an estimated $\$ 19$ billion in revenue in the U.S. in 2005 (Datamonitor, 2006a; Owers, 2005), and about $£ 1.2$ billion in U.K. (Datamonitor, 2006b). About half of that revenue comes from leisure travelers that fly to their vacation destinations (Shifrin, 2005; Stringer, 2004). Yet, in spite of the size of the rental market, there has been very little published research on the effects of marketing cues on consumers' rental behavior.

\section{LITERATURE REVIEW}

\section{Non-Tourism Oriented Research}

Studies have demonstrated the influence of such variables as price, brand, and distribution outlet on buyers' evaluations of both products and services (Tam 2004; Taylor and Baker 1994; Zeithaml, Berry and Parasuraman 1996). However, consumers often behave differently when choosing to rent products instead of purchasing them (Durgee and O'Conner, 1995). For example, consumers that lease vehicles have a greater desire for simplicity, gratification and variety than individuals that purchase their automobiles (Trocchia and Beatty, 2003). It is possible, then, that the influence that price, brand, and store have on outcome variables (i.e. consumer perceptions of quality, value, and willingness to buy) for rented products may differ from the influence that those same variables have for owned products.

In a study of the effects of extrinsic cues on perceptions of consumer goods, Dodds, Monroe, and Grewal (1991) employed as their units of analysis two electronic products - stereo headset players and calculators. The authors developed a conceptual model incorporating brand, price, and store as extrinsic cues influencing individuals' perceptions of quality, value, and willingness to buy consumer products. Their study's results revealed that price positively affected consumers' perceptions of quality but negatively impacted their willingness to buy. They also found, not surprisingly, that favorable brand and store information had a positive impact on subjects' willingness to buy the consumer goods depicted in the study, as well as perceptions of quality and value.

The Dodds, Monroe, and Grewal (1991) model (hereafter referred to as DMG) was extended to financial services by Ainscough, Ayub and Reyne (1999). In this study, the authors examined the effect of brand name, bank 
name and interest rate on consumer evaluation of credit cards. This resulted in different findings than the original DMG study in that interest rate (e.g. price) had significant negative impacts on quality, value and willingness to buy. This was due to the fact that consumers used high interest rate as a cue to recognize a card that was designed for people with bad credit - in other words, a low quality card. Bank (e.g. store) only had an effect on consumers' evaluation of quality, while brand had no significant impact on any dependent variable.

Tam (2004) examined the relationship among service quality, perceived value and customer satisfaction. This is one of the few studies in the services literature that examined these variables simultaneously-thereby allowing the relative impacts of the variables to be established. Results indicate that both perceived value and customer satisfaction significantly impacted consumers' post-purchase behavior. Clearly, the context within which consumers make these decisions has a powerful impact on their behavior.

\section{Tourism-Oriented Research}

Numerous recent studies have addressed consumer satisfaction with tourism, leisure, and travel services. For instance, in a highly managerially-relevant study, Wind et al. (1989) examined several hotel-appropriate variables, such as room layout and amenities, dining facilities, and security options. The study identified a marketplace gap between customer needs and hotel accommodations offered, precipitating the introduction of Marriott's Courtyard hotel chain for business travelers.

Chadee and Mattsson (1996) conducted a simulation using four tourist-related contexts: dining out, hotel accommodations, car rentals, and sightseeing tours. Like Fick and Ritchie (1991), they found that the tourism context had an influence on the relative importance that each variable (e.g. price, cleanliness, convenience) played in determining customer satisfaction with the tourism service. Hence, it is clear that blanket statements declaring particular attributes to be of greatest importance to tourists cannot be proffered.

Petrick, Morais, and Norman (2001) sought to find determinants of tourism repurchase intentions. They ascertained that past satisfaction with and perceived value of prior travel excursions were reliable predictors of future tourism purchases.

Ainscough (2005) conducted an experiment in the context of travel services that examined the effects of vacation price, travel agent name, and airline brand name on consumer perceptions of travel service quality, perceived service value, and willingness to purchase travel services. Results indicated that price of the vacation package was the only variable to have influenced study participants' willingness to purchase the travel package. However, airline and agent brand influenced consumers' perceptions of travel service quality.

Specifically in regards to car rentals, Grönroos and Sand (1993) conducted a case study in which they increased service offerings to consumers of car rental services. Results indicated that after increasing the level of service to consumers, revenues from rentals increased 15-23 percent. Because of its case study format, however, this study lacked a systematic manipulation of variables. Additional research is needed to determine which variables impact consumer perceptions and purchase intentions in this industry.

Although price, brand and store variables have been studied in other settings, no previous study could be found that has examined the relationship between these variables in a rental context even though it has been shown that consumers' perceptions can vary across products, purchase situations and time (Cooper 1969; Zeithaml 1988).

\section{RESEARCH OBJECTIVES}

This study's purpose is to ascertain the impact that price, brand and store variables have on quality and value perceptions as well as purchase intentions for a tangible good that is rented, rather than purchased. Renting is defined as a transaction in which one party offers an item to another party for a fixed period of time in exchange for money and in which there is no change in ownership (Obenberger and Brown, 1976). For this study, the authors chose rental cars as the context because of the previously mentioned size of the market and because of its relevance to tourism. Interestingly, rental of a tangible good possesses some characteristics of purchasing goods and some 
characteristics of consuming services. For instance, the rental car is a tangible good (a characteristic of a product) but the rental service is perishable, in that the rental vehicle only possesses utility for the relatively short period of time in which consumers are on vacation.

Based on the literature cited above, we proposed the following hypotheses:

\section{HYPOTHESES}

\section{Agency-Oriented Hypotheses}

$\mathbf{H 1}_{\mathbf{a}}$ : When quality perceptions of the rental car agency are higher, consumers' perceptions of the service quality are higher.

H2 $\mathbf{2}_{\mathbf{a}}$ : When quality perceptions of the rental car agency are higher, consumers' perceptions of value are higher.

$\mathbf{H 3}_{\mathbf{a}}$ : When quality perceptions of the rental car agency are higher, consumers' willingness to rent a vehicle are higher.

\section{Car Brand-Oriented Hypotheses}

H1 : When perceptions of the automobile brand name are more favorable, consumers' perceptions of service quality are higher.

H2 : When perceptions of the automobile brand name are more favorable, consumers' perceptions of value are higher.

$\mathbf{H 3}_{\mathbf{c}}$ : When perceptions of the automobile brand name are more favorable, consumers' willingness to rent the vehicle are higher.

\section{Price-Oriented Hypotheses}

H1 : When car rental prices are higher, consumer perceptions of service quality are higher.

$\mathbf{H 2}_{\mathrm{p}}$ : When car rental prices are higher, consumer perceptions of value are lower.

$\mathbf{H 3}_{\mathbf{p}}$ : When car rental prices are higher, consumers' willingness to rent a vehicle are lower.

\section{METHOD}

A $4 \times 2 \times 2$ between-subjects factorial design was used to test the hypotheses. This model is based on the model developed by Dodds et. al. (1991). The research design in this study includes four price levels (very high, high, moderate, low), two levels of rental car agency (Enterprise, U-Save), and two levels of brand/model (Buick LeSabre, Chevrolet Metro). The full factorial design is shown in Table 1.

Table 1. Research design*

\begin{tabular}{|c|c|c|c|c|c|}
\hline \multirow[b]{2}{*}{ Brand } & \multicolumn{4}{|c|}{ Price } & \multirow[b]{2}{*}{ Agent } \\
\hline & Very High & High & Medium & Low & \\
\hline High & 1 & 2 & 3 & 4 & High \\
\hline High & 5 & 6 & 7 & 8 & Low \\
\hline Low & 9 & 10 & 11 & 12 & High \\
\hline Low & 13 & 14 & 15 & 16 & Low \\
\hline
\end{tabular}

*The numbers in the table represent cells. For example, cell 10 represents high price, low automobile brand reputation and high rental agency reputation.

A pretest was carried out to determine the high and low levels for the brand and rental agency. The pretest gauged the customer service, trust, and prestige of a number of commonly rented car brands and local, as well as national, automobile rental agencies. The pretest resulted in the selection of "Buick LeSabre" and "Chevy Metro" as the high and low automobile brand names and "Enterprise" and "U-Save" as the high and low rental agency names, 
respectively. In addition to the pretesting, both of these variables were validated using manipulation checks in the final survey instrument as described below.

Price levels were determined by contacting a number of rental agencies for current rental rates. The median price was used as the moderate price in this study. High and low prices were determined by adding and subtracting $\$ 15$ from the moderate price level. The very high price was determined by adding $\$ 30$ to the high price level.

\section{Subjects}

Subjects were adult travelers in the upper Midwestern United States. The instrument was administered to the travelers by trained marketing students. Students were asked to administer the survey to respondents of varying demographic groups that met the qualifying requirements described below. This data collection technique has been successfully employed in a variety of market research studies (e.g. Trocchia and Janda, 2002; Gwinner, Gremler, and Bitner, 1998). Each researcher asked two qualifying questions designed to create a realistic pool of potential rental agency customers:

1. Have you rented a car in the past two years?

2. Are you at least 25 years of age? (Many agencies place restrictions on younger renters.)

Table 2. Multi-item scales

Perceived Quality Measures

Q1. The likelihood that the CSRs associated with this rental car agency would be reliable is:

$\begin{array}{llllllllll}\text { Very Low } & 1 & 2 & 3 & 4 & 5 & 6 & 7 & \text { Very High }\end{array}$

Q2. Compared to other rental agencies in the same area, this rental car is likely to be:

$\begin{array}{lllllllll}\text { Much Worse } & 1 & 2 & 3 & 4 & 5 & 6 & 7 & \text { Much Better } \\ \text { The rental package will be of: } & & & & & & \end{array}$

Q3. The rental package will be of:
Low Quality

Q4. The CSRs that I would deal with when renting this car would be helpful and courteous.

$\begin{array}{lllllllll}\text { Strongly Disagree } & 1 & 2 & 3 & 4 & 5 & 6 & 7 & \text { Strongly Agree } \\ \text { I would probably be treated very } & \text { well if I rented this car: } & & & & & \\ \text { Strongly Disagree } & 1 & 2 & 3 & 4 & 5 & 6 & 7 & \text { Strongly Agree }\end{array}$

\section{Perceived Value Measures}

V1. This rental car is a:

$\begin{array}{llllllll}\text { Poor Value } & 1 & 2 & 3 & 4 & 5 & 6\end{array}$

V2. This rental car appears to be a bargain:

$\begin{array}{lllllllll}\text { Strongly Disagree } & 1 & 3 & 4 & 5 & 6 & 7 & \text { Strongly Agree } \\ \text { At the price shown, the rental car is: } & & & & & & \end{array}$

V3. At the price shown, the rental car is:

V4. This rental car package is considered to be a good deal.

$\begin{array}{llllllllll}\text { Strongly Disagree } & 1 & 2 & 3 & 4 & 5 & 6 & 7 & \text { Strongly Agree } \\ \text { The price shown for this rental car is: } & & & & & \end{array}$

$\begin{array}{ccccccccc}\text { Very Unacceptable } & 1 & 2 & 3 & 4 & 5 & 6 & 7 & \text { Very Acceptable }\end{array}$

Willingness to Buy Measures

W1. The probability that you would consider renting this car is:

$\begin{array}{lllllllll}\text { Very Low } & 1 & 2 & 3 & 4 & 5 & 6 & 7 & \text { Very High }\end{array}$

W2. At the price shown, I would consider renting this car:

$\begin{array}{llllllllll}\text { Strongly Disagree } & 1 & 2 & 3 & 4 & 5 & 6 & 7 & \text { Strongly Agree }\end{array}$

W3. If I were going to rent a car, I would consider taking advantage of this package at the price shown.

$\begin{array}{lllllllll}\text { Strongly Disagree } & 1 & 2 & 3 & 4 & 5 & 6 & 7 & \text { Strongly Agree }\end{array}$

W4. The likelihood of me renting this car is:
Very Low
$2 \quad 3 \quad 4$

$5 \quad 6 \quad 7$
Very High

W5. My willingness to rent this car is: Very Low

\begin{tabular}{cllllllll} 
Very Low & 1 & 2 & 3 & 4 & 5 & 6 & 7 & Very High \\
\hline Adapted from Dodds, Monroe and Grewal $(1991)$ &
\end{tabular}


Respondents that answered both questions in the affirmative were invited to complete the remainder of the survey on their own. Vehicle photos were provided on the data collection instrument. All subjects were asked to provide a name and phone number for verification purposes. A random sample of 10 percent of the respondents were verified - all of them successfully.

One hundred forty eight subjects fitting the above criteria were included in the study. Seventy nine respondents were male; sixty nine were female. The median age category of our respondents was 44-49 years. Each subject evaluated one combination of price, rental agency and automobile model with regard to product quality, value, and willingness to buy on adapted DMG multi-item 7-point scales (Dodds et. al., 1991). The scales were modified slightly to accommodate the different product type (rental cars vs. consumer electronics) under examination in this study. The scale items are shown in Table 2.

\section{Dependent Variable Validation}

The scale items shown in Table 2 constitute multiple measures of the quality, value, and willingness to buy constructs. In order to ascertain whether each scale item measured the appropriate underlying construct (quality, value, or willingness to buy), a factor analysis (using the maximum likelihood method) with orthogonal rotation (VARIMAX with Kaiser normalization) was conducted. To determine the appropriateness of applying factor analysis to this data set, the Bartlett test of sphericity and the Kaiser-Meyer-Olkin Measure of Sampling Adequacy (MSA) were performed. The test of sphericity was significant $(\chi=1932, \mathrm{p}=.000)$, and the MSA was .914 , well above the .80 standard for a "meritorious" data set forth by Hair, et.al. (2006). Reliability analysis resulted in the following alpha values: Quality, .78; Value, .92; Willingness to buy, .96. Hair, et. al (2006, p. 137) suggest a minimum alpha level of .70 and these values are within that guideline.

All fifteen scale items were entered into the model. An eigenvalue of 1.00 or higher was used as the criterion for factor extraction. Factor rotation converged in five iterations. The rotated factor loadings are shown in Table 3. As expected, three factors (e.g. quality, value and willingness to buy) emerged from the analysis, and all fifteen of the scale items loaded on the expected factors.

This analysis showed that the scale items explained $69.3 \%$ of the variance in the model. Subsequent analysis proceeded using the mean scores of the items in each category.

Table 3. Rotated factor matrix

\begin{tabular}{cccc}
\hline & & Component & \\
\cline { 2 - 4 } Scale Item & Quality & Value & Willing to Buy \\
$\mathbf{Q}_{\mathbf{1}}$ & $\mathbf{. 5 1}$ & .05 & .13 \\
$\mathbf{Q}_{\mathbf{2}}$ & $\mathbf{. 4 4}$ & .14 & .47 \\
$\mathbf{Q}_{\mathbf{3}}$ & $\mathbf{. 4 8}$ & .32 & .41 \\
$\mathbf{Q}_{\mathbf{4}}$ & $\mathbf{. 8 3}$ & .14 &. .04 \\
$\mathbf{Q}_{\mathbf{5}}$ & $\mathbf{. 6 3}$ & .03 & .19 \\
$\mathbf{V}_{\mathbf{1}}$ & .34 & $\mathbf{. 4 6}$ & .42 \\
$\mathbf{V}_{\mathbf{2}}$ & .08 & $\mathbf{. 9}$ & .31 \\
$\mathbf{V}_{\mathbf{3}}$ & .07 & $\mathbf{. 8 3}$ & .23 \\
$\mathbf{V}_{\mathbf{4}}$ & .21 & $\mathbf{. 8 3}$ & .32 \\
$\mathbf{V}_{\mathbf{5}}$ & .11 & .87 & .30 \\
$\mathbf{W}_{\mathbf{1}}$ & .15 & .29 & $\mathbf{. 8 2}$ \\
$\mathbf{W}_{\mathbf{2}}$ & .12 & .60 & $\mathbf{. 6 6}$ \\
$\mathbf{W}_{\mathbf{3}}$ & .21 & .53 & $\mathbf{. 7 0}$ \\
$\mathbf{W}_{\mathbf{4}}$ & .26 & .38 & $\mathbf{. 8 4}$ \\
$\mathbf{W}_{\mathbf{5}}$ & .27 & .38 & $\mathbf{. 8 5}$ \\
\hline
\end{tabular}

A loading of .45 or greater is considered to be significant (Hair, et.al. 2006). Bold items loaded as expected. 


\section{Manipulation Checks}

In order to ascertain whether the consumers' perceived quality differences between the high and low levels of agent and brand, manipulation checks were conducted using seven-point rating scales (very high quality to very low quality). Upon completion of each questionnaire, all subjects were asked to evaluate a set of rental agencies and automobile brands. Decoys were included in the manipulation check questions in addition to the brands and agencies being examined in this study. A paired samples test was used to examine differences in perceptions for the high and low levels of both agency and automobile brand. Rental agency differences were significant $(\mathrm{p}=.000)$, indicating that consumers perceived a substantive difference in quality between Enterprise $(\overline{\mathrm{X}}=5.03)$ and U-Save $(\overline{\mathrm{X}}=3.55)$. Both of the brand manipulations also showed that consumers perceived a significant $(\mathrm{p}=.000)$ quality difference between Buick LeSabre ( $\overline{\mathrm{X}}=5.27)$ and Chevy Metro $(\overline{\mathrm{X}}=2.71)$.

\section{RESULTS}

\section{MANOVA Results}

The MANOVA results indicate that the main effects for price and brand are significant $(\mathrm{p}=.00)$. However, the rental agency main effect is not significant $(\mathrm{p}=.28)$. In addition, significant interaction effects occurred between price and rental agency as well as between price and car. The implications of these findings are addressed below. Table 4 presents the Wilks lambda statistics (Wilks), associated degrees of freedom (df), F-values and significance levels for the overall MANOVA and individual ANOVAs. The individual n's, cell means and standard deviations for each variable are shown in Table 5.

Table 4. Analysis of variance results

\begin{tabular}{|c|c|c|c|c|c|c|c|c|c|c|c|}
\hline \multirow[b]{3}{*}{ Effects } & \multirow{2}{*}{\multicolumn{3}{|c|}{ MANOVA }} & \multirow[b]{3}{*}{ Sig. $F$. } & \multirow[b]{3}{*}{ d.f. } & \multicolumn{6}{|c|}{ ANOVA } \\
\hline & & & & & & \multicolumn{2}{|c|}{ Quality } & \multicolumn{2}{|c|}{ Value } & \multicolumn{2}{|c|}{ Willingness to buy } \\
\hline & Wilks & d.f. & $F$-value & & & $F$ & $p$ & $F$ & $p$ & $F$ & $p$ \\
\hline Price (p) & .57 & 324 & 9.26 & .000 & 3 & 2.91 & .037 & 30.80 & .000 & 7.22 & .000 \\
\hline Agency (a) & .95 & 133 & 2.19 & .092 & 1 & 2.22 & .139 & 0.56 & .455 & 5.36 & .022 \\
\hline Car (c) & .69 & 133 & 20.33 & .000 & 1 & 18.46 & .000 & 6.34 & .013 & 51.88 & .000 \\
\hline $\mathrm{p} \times \mathrm{a}$ & .86 & 324 & 2.37 & .013 & 3 & 1.53 & .210 & 3.73 & .013 & 2.13 & .099 \\
\hline $\mathrm{p} \times \mathrm{c}$ & .80 & 324 & 3.52 & .000 & 3 & 0.69 & .563 & 2.90 & .037 & 7.55 & .000 \\
\hline $\mathrm{a} \times \mathrm{c}$ & .98 & 133 & 1.00 & .397 & 1 & 2.68 & .104 & 0.62 & .434 & 0.23 & .632 \\
\hline
\end{tabular}

Values in bold type significant at $\mathrm{p}<.05$

Table 5. Cell n's, means and standard deviations for perceived quality, perceived value, and willingness to buy

\begin{tabular}{llllllllll}
\hline & & & \multicolumn{3}{c}{ Price } & \multicolumn{3}{c}{ Agency } & \multicolumn{3}{c}{ Car } \\
& Level & V.High & High & Med. & Low & High & Low & High & Low \\
& n & 36 & 37 & 38 & 37 & 75 & 73 & 71 & 77 \\
\hline Perceived & Mean & 4.0 & 4.2 & 4.1 & 4.7 & 4.4 & 4.1 & 4.6 & 3.9 \\
Quality & S.D. & 1.1 & 1.0 & 1.2 & 0.9 & .94 & 1.1 & 0.9 & 1.2 \\
Perceived & Mean & 2.4 & 3.2 & 4.3 & 5.0 & 3.8 & 3.6 & 4.0 & 3.5 \\
Value & S.D. & 1.4 & 1.3 & 1.5 & 1.3 & 1.5 & 1.8 & 1.7 & 1.6 \\
Willingness & Mean & 2.2 & 2.7 & 3.3 & 3.5 & 3.2 & 2.6 & 3.8 & 2.1 \\
to Buy & S.D. & 1.4 & 1.7 & 1.8 & 2.0 & 1.8 & 1.8 & 1.7 & 1.5 \\
\hline
\end{tabular}

Means are on a seven point scale with 1 being low and 7 being high.

The results of Levene's Test of Homoscedasticity are shown in Table 6. The quality and value variables showed non-significant results indicating the presence of homoscedasticity. In the case of the willingness to buy variable, the significance level was .007 indicating the possible existence of heteroscedasticity. However, since the sample size is reasonably large and homoscedasticity is present in the other two variables, corrective remedies are not needed for the willingness to buy variable according to Hair, et.al. (2006, pg. 438). 
Table 6. Levene's Test of Equality of Error Variance

\begin{tabular}{lcccc}
\hline Variable & F & df1 & df2 & Sig. \\
\hline Quality & 1.647 & 15 & 132 & .070 \\
Value & 1.666 & 15 & 132 & .065 \\
Willingness to Buy & 2.275 & 15 & 132 & .007 \\
\hline
\end{tabular}

\section{Brand Effects}

Unlike other studies in the travel industry that examined the purchase of air transportation and hotel accommodations, brand — specifically the vehicle model being offered for rent—had a significant, direct impact on all three dependent variables: quality ( $\mathrm{p}=.000)$, value $(\mathrm{p}=.013)$, and willingness to rent $(\mathrm{p}=.000)$. This result confirms $\mathrm{H} 1_{c}, \mathrm{H} 2_{c}, H 3_{c}$, and is similar to the findings of the original DMG study of consumer products. Although all three variables were highly significant, an examination of the means and F-values indicates that the impact of brand on consumer willingness to buy is extremely strong. Indeed, this relationship had the largest F statistic and the second largest mean difference in the study.

\section{Agency Effects}

The only significant agency effect found in this study was the impact of agent on willingness to buy $(\mathrm{p}=.022)$. Although willingness to buy would appear to be the most important variable to most rental agencies, caution is urged in interpreting this result. Although the agency/willingness to buy relationship is significant, consumers do not perceive that a "better" rental agency results in a higher quality service experience or greater overall value. It may be that familiarity is driving this relationship. Respondents may simply have been more familiar with - and therefore more comfortable making a purchase from-Enterprise than U-Save. Pretests showed that Enterprise was perceived as being the highest quality of the major rental agencies. However if familiarity, rather than quality, is the main driver of willingness to buy, these results may have been different if another well known agency (e.g. Hertz) had been included in the study.

\section{Price Effects}

As expected, price has a significant inverse effect on consumer perceptions of value and willingness to buy, confirming $\mathrm{H} 2_{\mathrm{p}}$ and $\mathrm{H} 3_{\mathrm{p}}$. Price also had a significant inverse effect on perceived quality - the opposite effect predicted by the model-disconfirming $\mathrm{H}_{\mathrm{p}}$. This inverse effect is startling, and a review of the data shows that the entire effect is based on a large increase in quality perceptions in the low price scenarios. The effect occurs, to various degrees, in all low price cells. The authors believe that this result may be attributed to a halo effect (Beckwith, 1978) that occurs when customers are presented with a low price. For example, when a respondent sees a very low price on a familiar product (one in which quality level is well known) he or she may immediately have a positive reaction to the product that overrides the processing of subsequent information about that item.

\section{Interaction Effects}

Although no interactions were hypothesized, they were examined as a part of this study. The price/agent interaction had a significant impact on consumers' perceptions of value. In addition, the price/model interaction had a significant effect on both consumers' perceptions of value and consumers' willingness to buy. Both of these interaction terms have face validity, because it is reasonable to assume that consumers might use the combined information to judge the value of an offering and determine their willingness to buy it. For example, consumers might expect to pay more at a better agency or for a higher-end vehicle.

\section{DISCUSSION}

The findings of this paper indicate that rental agency had no impact on consumers' expectations for quality and value. However, agency did impact consumers' willingness to rent vehicles. The authors believe that this may be due to that fact that consumers are already familiar with the types of vehicles being offered for rent, so the agency 
impact on quality and value judgments took on a less influential role in attitude formation. Conversely, consumer willingness to rent may be attributed to familiarity with the rental agency. Further research is needed to determine whether, in fact, familiarity may be impacting consumer perceptions. If this finding is borne out in future research, it would justify rental car agencies spending more on institutional advertising and publicity (e.g. golf and tennis sponsorships), in order to make the agency name familiar to the traveling public.

Price had a significant impact on consumers' evaluations of quality and value, which were shown to lead to favorable purchase intentions. However, contrary to expectations, price had an inverse effect on perceived quality. An examination of the data revealed that this effect came exclusively from the low price cells. This result indicates that managers need not be concerned with cheapening the brand image by using price-oriented sales promotion.

As expected, automobile brand exerted a strong influence on all three dependent measures. These results are congruent with the results of the original DMG study and extant travel research. There was also a significant price by model interaction showing that consumers' attitudes toward value and their willingness to rent a vehicle were formed with respect to the specific model under consideration.

\section{LIMITATIONS AND FUTURE RESEARCH}

This study used a convenience sample, and as such the possibility exists that the individuals selected differ in some systematic way from the typical rental customer. In addition, this study made use of written scenarios simulating a rental offering rather than observing real-world purchasing patterns. Although such controlled measures have been shown to have high internal validity, external validity may be limited. Additional research should be conducted to determine whether these findings hold true in an actual rental context.

This study did not differentiate between business and leisure travelers. Since business travelers may be less concerned with the price variable, future research should be conducted to determine whether business travelers arrive at value judgments differently than their leisure counterparts.

Other factors, such as location of agency and availability of car models, may have a significant influence on consumer's decision processes. This study - like the original DMG model on which it is based-focuses only on price, brand and store. Future studies should attempt to integrate additional factors that may be of significance to the consumer decision process.

Furthermore, this study examined only American travelers. Additional research should be conducted in international settings in order to determine cultural influences on these variables. For example, since our findings may indicate that familiarity with a particular agency had a significant impact on consumer willingness to rent from that agency, using Hofstede's typology, further research could examine the impact of familiarity in cultures that are higher in uncertainty avoidance than the United States.

\section{AUTHOR INFORMATION}

Thomas L. Ainscough is an associate professor of marketing at University of South Florida St. Petersburg. He received his Ph.D. from University of Georgia. Professor Ainscough's research interests include services marketing, international marketing, and corporate social responsibility. His research is published in such journals as Marketing Letters, Journal of Macromarketing, Journal of Business Ethics, Journal of Consumer Marketing, Journal of Services Marketing, Journal of Marketing Education, and Journal of Travel and Tourism Marketing.

Philip J. Trocchia is an associate professor of marketing at University of South Florida St. Petersburg. He received his Ph.D. from University of Alabama. Professor Trocchia's research interests include services marketing, sports marketing, and consumer decision-making. His research is published in such journals as Psychology \& Marketing, European Journal of Marketing, Journal of Consumer Marketing, International Journal of Service Industry Management, Journal of Marketing Education, Journal of Management Education, and Journal of Services Marketing. 
John R. Gum is an instructor of decision sciences at the University of South Florida St. Petersburg. He earned his $\mathrm{Ph} . D$. in Industrial Engineering from Clemson University. Dr. Gums' research interest include optimization analysis and applied statistical analysis. His research is published in Ethics and Critical Thinking Journal, Leadership and Organizational Management Journal, and Computers \& Operations Research: An International Journal.

\section{REFERENCES}

1. Ainscough, TL., Brand name, agent name and vacation price influences on consumer evaluations of travel services. Journal of Travel and Tourism Marketing 19(1): 39-48, 2005.

2. Ainscough, TL, Ayub, O, and Reyne, P., Effects of brand name, bank name, and interest rate on consumer evaluations of credit cards. Journal of Financial Services Marketing 4(1): 37-48, 1999.

3. Beckwith, NE, Kassarjian, HH, and Lehmann, DR., Halo effects in marketing research: review and prognosis. Advances in Consumer Research, K. Hunt, ed., Ann Arbor, MI: Association for Consumer Research (5): 465-467, 1978.

4. Chadee, DD, and Mattsson, J., An empirical assessment of customer satisfaction in tourism. The Service Industries Journal 16(3): 305-320, 1996.

5. Cooper, P., Subjective economics: factors in a psychology of spending. Pricing Strategy. London: Staples Press, 112-121, 1969.

6. Datamonitor, Car rentals in the United Kingdom: Industry profile. London: Datamonitor plc (December), 2006.

7. Datamonitor, Car rentals in the United States: Industry profile. London: Datamonitor plc (December), 2006.

8. Dodds, WB, Monroe, KB, and Grewal, D., Effects of price, brand, and store information on buyers' product evaluations. Journal of Marketing Research 38(August): 307-319, 1991.

9. Durgee, JF, and O'Conner, G., An exploration of renting as consumption behavior. Psychology \& Marketing 12(March): 89-104, 1995.

10. Fick, GR, and Ritchie, JRB., Measuring service quality in the travel and tourism industry. Journal of Travel Research 30(Fall): 2-9, 1991.

11. Grönroos, C, S and Sand, HA., A winning service offer in car rental. Management_Decision 31(1): 45-57, 1993.

12. Gwinner, KP, Gremler, DD, and Bitner, MJ. Relational benefits in service industries: the customer's perspective. Journal of the Academy of Marketing Science 26 (Spring): 101-114, 1998.

13. Hair, JF, Black, WC, Babin, BJ., Anderson, RE and Tatham, RL., Multivariate Data Analysis. Prentice Hall: Upper Saddle River, NJ, 2006.

14. Obenberger, RW and Brown, SW., A marketing alternative: consumer leasing and renting. Business Horizons 19(October): 82-86, 1976.

15. Owers, P., Car-rental firms vying for off-airport sites. Knight Ridder Tribune Business News April 4: 1, 2005.

16. Petrick, J, Morais, D, and Norman, W., An examination of the determinants of entertainment vacationers' intentions to revisit. Journal of Travel Research 40(1): 41-48, 2001.

17. Shifrin, C., Price fights. Airline Business 21(7): 56-57, 2005.

18. Stringer, K., Travelers face higher rates on car rentals. The Wall Street Journal, February 19: D1, 2004.

19. Tam, JLM., Customer satisfaction, service quality and perceived value: an integrative model. Journal of Marketing Management 20(7, 8): 897-917, 2004.

20. Taylor, S, and Baker, T., An assessment of the relationship between service quality and customer satisfaction in the formation of consumers' purchase intentions. Journal of Retailing 70(2): 163-179, 1994.

21. Trocchia, PJ, and Beatty, SE., An empirical examination of automobile lease versus finance motivational processes. Journal of Consumer Marketing 20(1): 28-43, 2003.

22. Trocchia, PJ, and Janda, S. An investigation of product purchase and subsequent non-consumption. Journal of Consumer Marketing 19(2-3): 188-204, 2002.

23. Wind, J., Green, PE. Shifflet, D, and Scarbrough, M. Courtyard by Marriott: designing a hotel facility with consumer-based marketing models. Interfaces 19(1): 118-137, 1989.

24. Zeithaml, V. Consumer perceptions of price, quality, and value: a means-end model and synthesis of evidence. Journal of Marketing 52 (3): 2-22, 1988. 
25. Zeithaml, V, Berry, L, and Parasuraman, A. Behavioral consequences of service quality. Journal of Marketing 60(2): 31-46, 1996.

\section{NOTES}

